\title{
PRAKTIK PEMBERIAN SALINAN AKTA OLEH NOTARIS YANG MINUTA AKTANYA BELUM DITANDA TANGANI SECARA LENGKAP
}

\begin{abstract}
Alfin Dalfi
Universitas Andalas, alfindafli@gmail.com

Diterima: 23 Desember $2019 \quad$ Direvisi : 07 Juli $2020 \quad$ Diterbitkan: 09 Juli 2020

Abstract

In the routine inspection of the Padang Notary Regional Supervisory Council in 2019, according to his authority in Article 70 letter b UUJN 5 (five) findings of violations were found in the routine inspection of the Notary protocol where there was a violation in the form of incomplete signature of the notary deed. The formulation of this research is why in practice there was a giving of a copy of an act by a notary whose minutes of the deed had not been signed entirely and how the legal consequences of granting a copy of the deed by a notary whose minutes of the act had not been approved in full. This research is analytical descriptive research. Notary Deed has perfect proof of strength in a civil lawsuit, but if it violates specific provisions, the value of the evidence will be degraded to the strength of evidence as a deed under the hand. A notary who is proven to have made a mistake resulting in the act he made only has the power of proof as a deed under the side or even the deed is null and void by law, it will cause harm to the parties.
\end{abstract}

Keywords: Notary, Giving a Copy of Deed, Minutes Deed, Not Complete.

\begin{abstract}
Abstrak
Dalam pemeriksaan rutin Majelis Pengawas Daerah Notaris Padang di tabun 2019, sesuai dengan kewenangannya dalam Pasal 70 huruf b UUJN terjadi 5 (lima) temuan pelanggaran dalam pemeriksaan rutin terhadap protokol Notaris tersebut dimana terdapat pelanggaran berupa tidak. lengkapnya tanda tangan minuta akta Notaris. Rumusan penelitian ini adalah mengapa di dalam praktik terjadi pemberian salinan akta oleh Notaris yang minuta aktanya belum ditanda tangani secara lengkap dan bagaimana akibat hukum pemberian salinan akta oleh Notaris yang minuta aktanya belum ditanda tangani secara lengkap. Penelitian ini merupakan penelitian yang bersifat deskriptif analitis. Ak.ta Notaris mempunyai kekuatan pembuktian yang sempurna dalam gugatan perkara perdata, namun apabila melanggar ketentuan tertentu, akan terdegradasi nilai pembuktiannya menjadi kekuatan pembuktian sebagai akta di bawah tangan. Notaris yang terbukti melakukan kesalahan sehingga mengakibatkan akta yang dibuatnya hanya mempunyai kekuatan pembuktian sebagai akta di bawah tangan atau babkan akta batal demi bukum, maka akan menimbulkan kerugian bagi para pibak.
\end{abstract}

Kata Kunci : Notaris, Pemberian Salinan Akta, Minuta Akta, Belum Lengkap.

\section{PENDAHULUAN}

Dalam Undang-undang Dasar Negara Republik Indonesia Tahun 1945 dengan tegas dinyatakan bahwa Negara Republik Indonesia adalah negara hukum, dengan demikian salah satu tugas terpenting bagi pemerintah adalah memberikan dan menjamin adanya rasa kepastian hukum bagi masyarakat. Adanya kesadaran hukum yang tinggi pada masyarakat merupakan salah satu faktor yang mendorong masyarakat untuk membuat suatu perjanjian dihadapan Notaris. Kesadaran hukum yang tinggi pada masyarakat yang ditandai dengan semakin meningkatnya permintaan jasa Notaris, meningkatnya taraf hidup masyarakat dan adanya kemajuan teknologi yang begitu cepat serta semakin banyaknya lapangan usaha yang tersedia diberbagai bidang, sehingga menimbulkan dan mendorong para pelaku bisnis meningkatkan 
kegiatan usahanya diberbagai bidang. Oleh karena itu sangat diperlukan akan adanya akta Notaris dalam praktek lalu lintas hukum dalam masyarakat yang semakin maju dan kompleks. ${ }^{1}$

Kedudukan notaris sebagai seorang pejabat umum merupakan suatu jabatan terhormat yang diberikan oleh Negara secara atributif melalui Undang- undang, berdasarkan Pasal 2 Undang-undang Nomor 2 tahun 2014 tentang perubahan atas Undang-undang Nomor 30 tahun 2004 tentang Jabatan Notaris dan biasa disebut dengan UUJN (Undangundang Jabatan Notaris) yaitu Notaris diangkat dan diberhentikan oleh Menteri. Dengan diangkatnya seorang Notaris oleh Menteri Hukum Dan Hak Asasi Manusia, Notaris dapat menjalankan tugasnya dengan bebas, tanpa dipengaruhi badan eksekutif dan badan lainnya. Maksud kebebasan disini adalah agar Notaris dalam menjalankan jabatan nantinya dapat bertindak netral dan berdiri sendiri. Selain itu dalam mengemban tugasnya itu seorang Notaris harus memiliki tanggung jawab, yang artinya:

1. Notaris dituntut melakukan pembuatan akta dengan baik dan benar. Artinya akta yang dibuat itu menaruh kehendak hukum dan permintaan pihak berkepentingan karena jabatannya.

2. Notaris dituntut menghasilkan akta yang bermutu. Artinya akta yang dibuat itu sesuai dengan aturan hukum dan kehendak pihak yang berkepentingan dalam arti sebenarnya, bukan mengada-ada. Notaris harus menjelaskan kepada pihak yang berkepentingan kebenaran isi dan prosedur akta yang dibuatnya itu.

3. Berdampak positif, artinya siapapun akan mengakui isi akta Notaris itu mempunyai bukti yang sempurna. ${ }^{2}$

${ }^{1}$ G.H.S. Lumban Tobing,1983. Peraturan Jabatan Notaris, Erlangga, Jakarta, hlm.2.

2 Roesnatiti, Kode Etik Notaris (makalah disampaikan pada kuliah Kode Etik Notaris semester dua Program Studi Magister Kenotariatan Universitas
Jabatan yang diemban Notaris adalah suatu jabatan kepercayaan yang diamanatkan oleh Undang-undang dan masyarakat, seorang Notaris bertanggung jawab untuk melaksanakan kepercayaan yang diberikan kepadanya dengan selalu menjunjung tinggi etika hukum dan martabat serta keluhuran jabatannya, sebab apabila hal tersebut diabaikan oleh seorang Notaris akan berdampak bagi masyarakat umum yang dilayaninya.

Akta Notaris merupakan alat bukti tulisan atau surat yang bersifat sempurna, karena akta Notaris mempunyai 3 (tiga) kekuatan pembuktian, yaitu:

1. Kekuatan pembuktian lahiriah (uitwendigebewijskracht) yang merupakan kemampuan akta itu untuk memberikan keabsahannya sebagai akta autentik.

2. b. Kekuatan pembuktian formil (formelebewijskracht) yang memberikan kepastian bahwa sesuatu kejadian dan fakta tersebut dalam akta betul-betul diketahui dan didengar oleh Notaris dari keterangan oleh para pihak yang menghadap, yang tercantum dalam akta sesuai dengan prosedur yang sudah ditentukan dalam pembuatan akta Notaris.

3. Kekuatan pembuktian materil (materiele bewijskracht) yang merupakan tentang kepastian tentang materi suatu akta.

Jabatan Notaris diatur dalam Undangundang Nomor 2 tahun 2014 tentang perubahan atas Undang-Undang Nomor 30 tahun 2004 tentang Jabatan Notaris. Semua hal tentang notaris harus mengacu pada Undangundang tersebut, baik menyangkut kewenangan, kewajiban dan larangan dalam menjalankan jabatan notaris tersebut. Dalam sumpah jabatan notaris disebutkan bahwa seorang notaris haruslah menjalankan

Indonesia, Depok, Maret 2009), hlm.64. http:/ /ib.ui.ac.id/ file?file=digital/135538-T\%2027970Peran\%20notaris-Analisis.pdf, di akses tanggal 28 September 2019, pukul 11.00 WIB. 
jabatannya dengan jujur, seksama dan tidak memihak. Seorang notaris juga harus patuh dan taat dengan seteliti-telitinya semua peraturanperaturan dan nilai moral bagi jabatan notaris yang sedang berlaku atau akan diadakan. Hal ini berarti bahwa seorang notaris harus tetap memperhatikan seluruh Peraturan Perundangundangan yang ada dan masih berlaku di Indonesia agar dapat menyesuaikan dengan akta yang dibuatnya tersebut, sehingga dapat menghindari kesalahan-kesalahan yang mungkin dapat terjadi karena bertentangan dengan Peraturan Perundang-undangan yang ada dimana hal tersebut dapat mengakibatkan aktanya menjadi kehilangan otensitasnya atau terdegradasi menjadi akta dibawah tangan.

Notaris dalam menjalankan salah satu kewajibannya sebagaimana terdapat dalam Pasal 16 angka 1 huruf b UUJN bahwa membuat akta dalam bentuk minuta akta dan menyimpannya sebagai bagian dari protokol Notaris. Pada dasarnya menyimpan minuta akta itu adalah kewajiban Notaris, sehingga Notaris seharusnya menyimpan sendiri protokol Notaris (yang berisi minuta akta) dan tidak membiarkan protokol Notaris dipegang oleh pegawainya. Ini karena protokol Notaris adalah kumpulan dokumen yang merupakan arsip negara yang harus disimpan dan dipelihara oleh Notaris, hal ini diatur pada Pasal 1 angka 13 UUJN.

Pengertian minuta akta diatur dalam Pasal 1 angka 8 UUJN yaitu minuta akta adalah asli akta yang mencantumkan tanda tangan para penghadap, saksi, dan Notaris, yang disimpan sebagai bagian dari protokol Notaris. Minuta akta bisa dikatakan sebagai nyawa seorang Notaris karena minuta merupakan sumber utama akta Notaris, tanpa adanya minuta maka tidak akan ada salinan/turunan atau kutipan akta. Dalam minuta terdapat kehendak para penghadap atau para pihak dan dibagian akhir akta tertera tanda tangan para pihak, Notaris, dan para saksi. Sebelum akta itu ditanda tangani, Notaris wajib membacakan isi dari akta tersebut kepada para penghadap atau pihak agar di mengerti oleh para penghadap atau para pihak dan memberikan paraf pada setiap halaman akta tersebut.

Hal ini diatur dalam Pasal 16 angka 1 huruf $m$ dimana dalam menjalankan jabatannya, Notaris wajib; membacakan akta dihadapan penghadap dengan dihadiri oleh paling sedikit 2 (dua) orang saksi, atau 4 (empat) orang saksi khusus untuk pembuatan akta wasiat dibawah tangan, dan ditanda tangani pada saat itu juga oleh penghadap, saksi, dan Notaris. Hal ini jelas disebutkan bahwa akta Notaris ditanda tangani pada saat setelah akta dibacakan dihadapan penghadap. Apabila Notaris tidak memiliki minuta akta lengkap, bagaimana kepastian hukum salinan akta yang dibuatnya. Pembuatan salinan akta harus berpedoman pada minuta aktanya. Salinan akta ada setelah minuta dibuat dan telah ditanda tangani dengan sempurna.

Pengertian salinan akta diperjelas dalam Pasal 1 angka 9 UUJN yaitu salinan akta adalah salinan kata demi kata dari seluruh akta dan pada bagian bawah salinan akta tercantum frasa "diberikan sebagai salinan yang sama bunyinya". Dalam salinan akta ada pernyataan Notaris dimulai dari awal akta dan akhir akta dan dalam salinan hanya terdapat tanda tangan Notaris. Awal akta menerangkan bahwa para pihak telah menghadap kepada Notaris, dan pada akhir ada keterangan mengenai akta tersebut telah ditanda tangani dengan sempurna dan salinan yang sama bunyinya.

Alur pembuatan akta ini sudah seharusnya menjadi perhatian Notaris karena sudah diatur dalam Pasal 16 angka 1 huruf $m$ UUJN sehingga tidak boleh ada kewenangan dan kewajiban Notaris yang menyimpang atau bertentangan dengan Undang-undang tersebut. Namun masih saja terjadi pelanggaran yang ditemukan oleh Majelis Pengawas Notaris dengan tidak dilengkapinya tanda tangan dalam minuta akta Notaris pada saat dilakukan pemeriksaan terhadap minuta akta Notaris. Dalam pemeriksaan rutin Majelis Pengawas 
Daerah Notaris Padang di tahun 2019, sesuai dengan kewenangannya dalam Pasal 70 huruf b UUJN terjadi 5 (lima) temuan pelanggaran dalam pemeriksaan rutin terhadap protokol Notaris tersebut dimana terdapat pelanggaran berupa tidak lengkapnya tanda tangan minuta akta Notaris.

Berdasarkan latar belakang tersebut, penelitian ini diteliti dan dilaksanakan. Untuk itu masalah penelitian ini adalah mengapa di dalam praktik terjadi pemberian salinan akta oleh Notaris yang minuta aktanya belum ditanda tangani secara lengkap. Selain itu, fokus penelitian ini adalah bagaimana akibat hukum pemberian salinan akta oleh Notaris yang minuta aktanya belum ditanda tangani secara lengkap.

\section{METODE PENELITIAN}

Secara mendasar, penelitian jenis penelitian ini adalah penelitian ilmu Hukum. Ilmu hukum mempunyai karakteristik sebagai ilmu yang bersifat preskriptif dan terapan. Sebagai ilmu yang bersifat preskriptif, ilmu hukum mempelajari tujuan hukum, nilai-nilai, keadilan, validalitas aturan hukum, konsepkonsep hukum, dan norma-norma hukum. ${ }^{3}$ Dengan karakteristik seperti itu, karena kajiannya terletak pada norma dan kaidah hukum yang mengatur maka pendekatan masalah yang akan dipergunakan dalam penelitian ini adalah pendeketan Yuridis Normatif. Menurut F. Sugeng Istanto, penelitian hukum adalah penelitian yang diterapkan atau diperlakukan khusus pada ilmu hukum. ${ }^{4}$
Penelitian ini merupakan penelitian yang bersifat deskriptif analitis yaitu hasil yang diperoleh dalam penelitian ini mampu memberikan gambaran tentang bagaimana praktik pemberian salinan akta oleh Notaris yang minuta aktanya belum ditanda tangani secara lengkap. Hal ini sesuai dengan tujuan penelitian deskriptif adalah penelitian yang bertujuan untuk secara sistematis, faktual, dan akurat terhadap objek yang menjadi pokok masalah. $^{5}$

Teknik pengumpulan data pada penelitian ini adalah dengan penelitian kepustakaan (library research) untuk mendapatkan kajian-kajian teori mendasar sebagai landasan teoritis; primer; sekunder; dan tersier. Bahan hukum primer yang digunakan adalah; Undang-Undang Dasar Negara Republik Indonesia Tahun 1945; Kitab Undang-Undang Hukum Perdata; UndangUndang Nomor 30 Tahun 2004 tentang Jabatan Notaris; Undang-Undang Nomor 2 Tahun 2014 tentang Perubahan Atas Undang-Undang Nomor 30 Tahun 2004 tentang Jabatan Notaris; Kode Etik Notaris Tahun 2005; Perubahan Kode Etik Notaris Kongres Luar Biasa Ikatan Notaris Indonesia Tahun 2015; Peraturan Menteri Hukum dan Hak Asasi Manusia Republik Indonesia Nomor: M02.PR.08.10 Tahun 2004 tentang Tata Cara Pengangkatan Anggota, Susunan Organisasi, Tata Kerja, dan Tata Cara Pemeriksaan Majelis Pengawas Notaris. Selanjutnya, data utama penelitian didapatkan dengan wawancara berbagai informan. ${ }^{6}$

Hakim Konstitusi dalam Konsepsi Negara Hukum, Penelitian Badan Pembinaan Hukum Nasional (BPHN) Tahun 2014, Jakarta, hlm.10.

5 Sugiyono,2009, Metode Penelitian Bisnis, CV. Alfabeta, Bandung, hlm.23.

6 Bambang Sunggono,2003, Metodologi Penelitian Hukum Edisi II Cet.5, JPT. Raja Grafindo Persada, Jakarta, hlm.116-117. 
PERAN NOTARIS DALAM

\section{PANDANGAN AKTA AUTENTIK}

Notaris mempunyai peran untuk memberikan penyuluhan hukum sehubungan dengan pembuatan akta. Notaris juga mempunyai kewenangan untuk mengesahkan tanda tangan dan menetapkan kepastian tanggal surat di bawah tangan dengan mendaftar dalam buku khusus. Di akhir atau penutup akta yang dibuat dihadapan Notaris memuat uraian tentang penandatanganan dan tempat penandatanganan atau penerjemah akta jika ada. Dalam membuat akta autentik, penandatanganan merupakan hal yang wajib harus dibubuhkan oleh penghadap karena akta autentik yang dibuat dihadapan Notaris yang dalam hal ini minuta akta adalah asli akta yang mencantumkan tanda tangan para penghadap, saksi, dan Notaris. Pada dasarnya, fungsi tanda tangan adalah menjamin kepastian tanggal dan untuk menjamin kepastian para pihak tidak mengelak tentang isi akta sehingga akan mengikat secara hukum bagi para pihak.

Mekanisme penandatanganan akta autentik tidak hanya terbatas pada persoalan bahwa akta tersebut harus ditandatangani namun penandatanganan akta tersebut harus dihadapan Notaris sebagaimana telah diatur dalam Pasal 16 angka 1 huruf m UUJN bahwa "membacakan akta dihadapan penghadap dengan dihadiri oleh paling sedikit 2 (dua) orang saksi, atau 4 (empat) orang saksi khusus untuk pembuatan akta wasiat dibawah tangan dan ditandatangani pada saat itu juga oleh penghadap, saksi, dan Notaris". Membacakan akta sampai pada penandatanganan adalah satu kesatuan dari peresmian akta dimana sebelum akta tersebut ditanda tangani terlebih dahulu akta tersebut dibacakan didepan para pihak yang bersangkutan guna menyampaikan kebenaran isi akta dengan keinginan para pihak kemudian akta tersebut ditandatangani tentunya dihadapan para pihak dan 2 (dua) orang saksi.
Akta Notaris sebagai alat bukti agar mempunyai kekuatan pembuktian yang sempurna. Jika seluruh ketentuan prosedur atau tata cara pembuatan akta dipenuhi. Jika ada prosedur yang tidak dipenuhi, dan prosedur yang tidak dipenuhi tersebut dapat dibuktikan, maka akta tersebut dengan proses pengadilan dapat dinyatakan sebagai akta yang mempunyai kekuatan pembuktian sebagai akta dibawah tangan. Jika sudah berkedudukan seperti itu maka nilai pembuktiannya diserahkan kepada Hakim.

Akta Notaris berisi keterangan dan pernyataan para pihak, dibuat atas kehendak atau permintaan para pihak, dan Notaris membuat dalam bentuk yang sudah ditentukan menurut Undang-undang. Notaris bukan pihak dalam akta tersebut, pencantuman nama Notaris dalam akta karena perintah Undangundang. Membatalkan akta Notaris berarti secara lahiriah tidak mengakui akta tersebut, dengan demikian akta tersebut bukan akta Notaris. Penilaian akta Notaris secara lahiriah bukan akta Notaris, maka harus dibuktikan dari awal sampai dengan akhir akta, bahwa ada syarat yang tidak dipenuhi mengenai bentuk suatu akta Notaris. Jika dapat dibuktikan bahwa akta Notaris tersebut tidak memenuhi syarat sebagai sebuah akta Notaris, maka akta tersebut mempunyai nilai pembuktian sebagaimana akta dibawah tangan, yang penilaian pembuktiannya tergantung pada pengakuan para pihak dan hakim.

Ketentuan normatif ini mengatur Notaris agar dalam menjalankan profesinya selalu terkontrol dengan formalitas yang telah digariskan. Artinya tuntutan profesi Notaris lebih merujuk pada bentuk dari akta yang dihasilkan bukan substansi (materi) dari akta. Oleh karenanya, suatu tindakan yang keliru dari Notaris dalam menjalankan pekerjaannya tidak hanya akan merugikan Notaris itu sendiri namun juga dapat merugikan masyarakat, Negara bahkan organisasi profesi. 
Perkara pidana dan perdata akta Notaris senantiasa dipermasalahkan dari aspek formal, terutama mengenai:

1. Kepastian hari, tanggal, bulan, tahun, dan pukul menghadap.

2. Pihak (siapa) yang menghadap Notaris.

3. Tanda tangan yang menghadap.

4. Salinan akta yang tidak sesuai dengan minuta akta.

5. Salinan akta ada, tanpa dibuat minuta akta.

6. Minuta akta tidak ditanda tangani secara lengkap, tapi minuta akta dikeluarkan.

\section{MAJELIS PENGAWAS NOTARIS SEBAGAI INSTANSI YANG MELAKUKAN PENGAWASAN, PEMERIKSAAN, DAN MENJATUHKAN SANKSI TERHADAP NOTARIS}

Dalam menjalankan tugas jabatannya Notaris diawasi oleh instansi yakni Majelis Pengawas Notaris yang melakukan pengawasan, pemeriksaan, dan menjatuhkan sanksi terhadap Notaris, dengan tujuan agar para Notaris dalam menjalankan tugas jabatannya memenuhi semua persyaratan yang berkaitan dengan tugas jabatan Notaris, demi untuk pengamanan kepentingan masyarakat, karena Notaris diangkat oleh Pemerintah, bukan untuk kepentingan diri Notaris sendiri melainkan untuk kepentingan masyarakat yang dilayaninya.

Meskipun demikian dengan adanya Majelis Pengawas Notaris tidak berarti tidak akan terjadi pelanggaran-pelanggaran yang dilakukan Notaris, karena betapapun ketatnya pengawasan yang dilakukan Majelis Pengawas Notaris, kesadaran dan tanggung jawab secara penuh dalam tugas jabatannya dikembalikan pada Notaris itu sendiri. Pengawasan dan pemeriksaan terhadap Notaris yang dilakukan oleh Majelis Pengawas, yang di dalamnya ada unsur Notaris, dengan demikian setidaknya Notaris diawasi dan diperiksa oleh anggota
Majelis Pengawas yang memahami dunia Notaris.

Adanya anggota Majelis Pengawas dari kalangan Notaris merupakan pengawasan internal, artinya dilakukan oleh sesama Notaris yang memahami dunia Notaris luar-dalam. Sedangkan unsur lainnya merupakan unsur eksternal yang mewakili dunia akademik, pemerintah, dan masyarakat. Perpaduan keanggotaan Majelis Pengawas diharapkan dapat memberikan sinergi pengawasan dan pemeriksaan yang objektif, sehingga setiap pengawasan dilakukan berdasarkan aturan hukum yang berlaku, dan para Notaris dalam menjalankan tugas dan jabatannya tidak menyimpang dari UUJN karena diawasi secara internal dan eksternal.

Dari hasil kegiatan pemeriksaan protokol Notaris sesuai dengan Pasal 70 huruf b UUJN, Majelis Pengawas Daerah Kota Padang yang wilayahnya meliputi Kota Padang dan Kabupaten Pesisir Selatan masih ditemukan pelanggaran terhadap minuta akta yang tidak ditanda tangani secara lengkap. Untuk pemeriksaan dari awal tahun 2019 sampai sekarang tim pemeriksa menemukan sebanyak 5 (lima) pelanggaran terhadap minuta akta tersebut. Temuan pelanggaran ini dimuat dalam berita acara pemeriksaan oleh tim pemeriksa dengan ditandatangani oleh tim dan Notaris yang diperiksa. Evaluasi dan tindak lanjut dilakukan oleh tim pemeriksa dengan dilakukannya pemanggilan terhadap Notaris yang melakukan pelanggaran untuk dilakukan pembinaan. Untuk tahap awal pembinaan dilakukan dengan memberikan teguran secara lisan dan apabila pada pemeriksaan selanjutnya tidak ada perbaikan atau perubahan maka 
Notaris yang bersangkutan akan dipanggil dan diberikan peringatan secara berjenjang. ${ }^{7}$

\section{Dalam menjalankan jabatannya,} Notaris seringkali dihadapkan berbagai macam persoalan, mulai dari persoalan antar sesama Notaris, persoalan para pihak yang tidak mempunyai kesepahaman dan kesepakatan dalam pembuatan perjanjian, bahkan sampai kepada persoalan hubungan kerjasama dengan pihak terkait sebagai mitra kerja Notaris. Jika persoalan tersebut tidak disikapi secara bijaksana (di luar koridor hukum) oleh Notaris, maka anggapan yang mengatakan Notaris hanya tukang pembuat akta memang ada benarnya. Apalagi dengan alasan menjaga hubungan baik dengan relasi, lantas mengabaikan kaedah normatif yang ada. Hal ini justru semakin menelanjangi profesi Notaris di mata hukum dan masyarakat. Masyarakat akan menganggap Notaris sama halnya dengan seorang partikelir yang hanya mencari keuntungan atas profesinya. ${ }^{8}$

Stigma yang menganggap Notaris sama halnya dengan seorang partikelir merupakan suatu fenomena yang tidak terbantahkan. Fakta itu semakin melekat dan tercermin dari sikap dan perilaku Notaris yang tidak lagi mengindahkan kaidah hukum yang berlaku. Notaris semakin asyik dengan parodi serta kamuflase masyarakat yang membutuhkan jasa Notaris. Dalam hal ini hukum tidak dianggap lagi sebagi panglima, akan tetapi sebagai alat untuk melegitimasi setiap perbuatan yang mereka lakukan. ${ }^{9}$

Sebagai akibat dari kurangnya kesadaran terhadap peraturan yang mengatur jabatan Notaris tersebut, tentu tidak hanya akan menimbulkan efek bagi Notaris sendiri yakni diberikannya sanksi atas pelanggaran, juga

7 Wawancara Arif Endra Susilo, SH, Sekretaris MPD Notaris Kota Padang, Pada tanggal 14 September 2019, Pukul 10.00 WIB.

8 Azmi Fendri, Strategi Notaris Dalam Menghadapi Perkara Pidana/Perdata Dalam Kaitannya Dengan Kewenangan $M P D$ dan $M K N$, Makalah disampaikan pada Acara Up terhadap para pihak didalam akta tersebut. Pelanggaran yang dilakukan oleh Notaris juga merupakan pelanggaran terhadap pedoman sikap dan tingkah laku jabatan Notaris. Hal ini sesuai dengan yang ditegakkan oleh organisasi Notaris dalam melaksanakan profesi Notaris.

Hubungan profesi Notaris dengan organisasi profesi Notaris diatur melalui kode etik Notaris yang ditetapkan dan ditegakkan oleh organisasi Notaris. Keberadaan kode etik Notaris merupakan konsekuensi logis dari dan untuk suatu pekerjaan yang disebut sebagai profesi. Bahkan ada pendapat yang menyatakan bahwa Notaris sebagai pejabat umum yang diberikan kepercayaan harus berpegang teguh tidak hanya pada peraturan Perundangundangan semata, namun juga pada kode etik profesinya, karena tanpa kode etik, harkat dan martabat dari profesinya akan hilang.

Nilai-nilai etika itu tidak hanya milik satu atau dua orang, atau segolongan orang saja, tetapi milik setiap kelompok masyarakat, bahkan kelompok yang paling kecil yaitu keluarga sampai satu bangsa. Dengan nilai-nilai etika tersebut, suatu kelompok diharapkan akan mempunyai tata nilai untuk mengatur kehidupan bersama. Salah satu golongan masyarakat yang mempunyai nilai-nilai yang menjadi landasan dalam pergaulan baik dalam kelompok atau masyarakat umumnya maupun dengan sesama anggotanya, yaitu masyarakat profesional. Golongan ini sering menjadi pusat perhatian karena adanya tata nilai yang mengatur dan tertuang secara tertulis (yaitu kode etik profesi) dan diharapkan menjadi pegangan para anggotanya.

Sorotan masyarakat menjadi semakin tajam manakala perilaku-perilaku sebagian para anggota profesi yang tidak didasarkan pada

Grading Ikatan Notaris Indonesia Wilayah Sumatera Barat Pengurus Daerah Pariaman tanggal 27 Maret 2017 , di Pariaman. http://mkn.usu.ac.id/images/9.pdf, di akses tanggal 2 Desember 2019, pukul 10.00 WIB ${ }^{9}$ Ibid. 
nilai-nilai pergaulan yang telah disepakati bersama (tertuang dalam kode etik profesi), sehingga terjadi kemerosotan etik pada masyarakat profesi tersebut. Kode etik profesi adalah sistem norma, nilai dan aturan profesional tertulis yang secara tegas menyatakan apa yang benar dan yang baik, dan apa yang tidak benar dan yang tidak baik bagi profesional. Kode etik menyatakan perbuatan apa yang benar dan salah, perbuatan apa yang harus dilakukan dan harus dihindari. Tujuan kode etik yaitu agar profesional memberikan jasa sebaik-baiknya kepada pemakai atau nasabahnya. Dengan adanya kode etik akan melindungi perbuatan yang tidak profesional.

Akta autentik memberikan bukti yang mengikat dan sempurna terhadap para pihak (beserta ahli waris mereka) atau mereka yang memperoleh hak dari para pihak itu, hal ini sesuai dengan ketentuan Pasal 1870 KUHPerdata yang berbunyi : "suatu akta untuk memberikan diantara para pihak beserta ahli warisnya atau orang-orang yang mendapat hak ini dari mereka, suatu bukti yang sempurna tentang apa yang dimuat didalamnya".

Kekuatan yang melekat pada akta autentik yaitu sempurna (volledig bewijskracht) dan mengikat (bindende bewijskracht), yang berarti apabila alat bukti akta autentik diajukan memenuhi syarat formil, materil dan jika bukti lawan yang dikemukan tergugat tidak mengurangi keberadaannya, pada dirinya sekaligus melekat kekuatan pembuktian yang sempurna dan mengikat (volledig en bindende bewijjkracht), dengan demikian kebenaran isi dan pernyataan yang tercantum didalamnya menjadi sempurna dan mengikat kepada para pihak mengenai apa yang disebut dalam akta. Sempurna dan mengikat kepada hakim sehingga hakim harus menjadikanya sebagai dasar fakta sempurna dan cukup untuk mengambil putusan atas penyelesaian perkara yang disengketakan. ${ }^{10}$

Sebagai pejabat umum (openbaar ambtenaar) Notaris berwenang membuat akta autentik. Sehubungan dengan kewenangannya tersebut Notaris dapat dibebani tanggung jawab atas perbuatan/ pekerjaannya dalam membuat akta autentik. Tanggung jawab Notaris sebagai pejabat umum meliputi tanggung jawab profesi Notaris itu sendiri yang berhubungan dengan akta, diantaranya; pertama, tanggung jawab Notaris secara perdata atas akta yang dibuatnya. Tanggung jawab dalam hal ini adalah tanggung jawab terhadap kebenaran materil akta, dalam konstruksi perbuatan melawan hukum. Perbuatan hukum disini dalam sifat aktif maupun pasif. Aktif dalam artian melakukan perbuatan yang menimbulkan kerugian pada pihak lain. Sedangkan pasif, dalam artian tidak melakukan perbuatan yang merupakan keharusan, sehingga pihak lain menderita kerugian. Jadi unsur dari perbuatan melawan hukum disini yaitu adanya perbuatan melawan hukum, adanya kesalahan dan adanya kerugian yang ditimbulkan.

Kedua, tanggung jawab Notaris secara pidana atas akta yang dibuatnya. Pidana dalam hal ini adalah perbuatan pidana yang dilakukan oleh seorang Notaris dalam kapasitasnya sebagai pejabat umum yang berwenang membuat akta, bukan dalam konteks individu sebagai warga Negara pada umumnya. Ketiga, tanggung jawab Notaris secara administrasi atas akta yang dibuatnya. Sanksi administrasi berdasarkan UUJN menyebutkan ada 5 (lima) jenis sanksi administrasi yang diberikan apabila seorang Notaris melanggar ketentuan UUJN yaitu, a. Peringatan lisan; b. Peringatan tertulis; c. Pemberhentian sementara; d. Pemberhentian dengan hormat; e. Pemberhentian dengan tidak hormat.

${ }^{10}$ Christin Sasauw, 2015, Tinjauan Yuridis Tentang Kekuatan Mengikat Suatu Akta Notaris, Jurnal Lex Privatum, Vol.III/No.1, hlm.100. 
Akta Notaris mempunyai kekuatan pembuktian yang sempurna dalam gugatan perkara perdata, namun apabila melanggar ketentuan tertentu, akan terdegradasi nilai pembuktiannya menjadi kekuatan pembuktian sebagai akta di bawah tangan, Notaris yang terbukti melakukan kesalahan sehingga mengakibatkan akta yang dibuatnya hanya mempunyai kekuatan pembuktian sebagai akta di bawah tangan atau bahkan akta batal demi hukum, maka akan menimbulkan kerugian bagi para pihak. Notaris dapat dimintakan pertanggungjawaban atas kesalahan tersebut dan diwajibkan memberi ganti rugi, biaya, dan bunga kepada para pihak yang menderita kerugian.

\section{KESIMPULAN}

Dalam Undang-undang Jabatan Notaris, pengertian akta auntentik diatur dalam Pasal 1 angka 7 yakni akta Notaris yang selanjutnya disebut dengan akta adalah akta autentik yang dibuat oleh atau dihadapan Notaris menurut bentuk dan tata cara yang ditetapkan dalam Undang-undang ini. Salah satu kewajiban Notaris dalam pembuatan akta yaitu diatur dalam Pasal 16 ayat 1 huruf m dimana setelah dibacakan oleh Notaris, akta langsung ditanda tangani oleh penghadap, Notaris dan saksi Notaris sehingga menjadi minuta akta yang merupakan bagian dari protokol Notaris. Jika salah satu syarat sebagaimana dimaksud pada ayat 1 huruf $m$ tidak dipenuhi, akta yang bersangkutan hanya mempunyai kekuatan pembuktian sebagai akta dibawah tangan. Hal ini juga diatur dalam Pasal 1869 KUHPerdata yaitu suatu akta yang tidak dapat diperlakukan sebagai akta autentik, baik karena tidak berwenang atau tidak cakapnya pejabat umum yang bersangkutan maupun karena cacat dalam bentuknya mempunyai kekuatan sebagai tulisan di bawah tangan bila ditandatangani oleh para pihak.

Akta Notaris mempunyai kekuatan pembuktian yang sempurna dalam gugatan perkara perdata, namun apabila melanggar ketentuan tertentu, akan terdegradasi nilai pembuktiannya menjadi kekuatan pembuktian sebagai akta di bawah tangan. Notaris yang terbukti melakukan kesalahan sehingga mengakibatkan akta yang dibuatnya hanya mempunyai kekuatan pembuktian sebagai akta di bawah tangan atau bahkan akta batal demi hukum, maka akan menimbulkan kerugian bagi para pihak. Notaris dapat dimintakan pertanggungjawaban atas kesalahan tersebut dan diwajibkan memberi ganti rugi, biaya, dan bunga kepada para pihak yang menderita kerugian.

Notaris selaku pejabat umum yang berwenang membuat akta autentik dalam menjalankan jabatan seharusnya, mampu memahami dan melaksanakan Peraturan Perundang-undangan dan Kode Etik Notaris sebagai pedoman dalam melaksanakan profesi Notaris. Dan dalam menjalankan tugas profesinya Notaris harus bekerja secara profesional dan bertanggung jawab terhadap apa yang menjadi tugas dan tanggung jawabnya.

Masyarakat yang menggunakan jasa Notaris seharusnya lebih peduli terhadap produk hukum yang dibuat Notaris apakah telah di buat dengan benar dan sesuai dengan Peraturan yang ada dan menjamin masyarakat memperoleh kepastian hukum. Dan apabila dapat dibuktikan tidak sesuai dengan Peraturan yang mengaturnya masyarakat dapat melaporkan kepada Majelis Pengawas Notaris agar dapat diproses terhadap adanya pelanggaran tersebut, dan diberikan sanksi tegas sesuai dengan Peraturan Perundang-undangan yang berlaku, agar dapat lebih meningkatkan kesadaran Notaris dalam melaksanakan tugas dan tanggung jawabnya sesuai dengan Peraturan Perundang-undangan dan Kode Etik yang berlaku, sehingga tidak menimbulkan kerugian baik terhadap Notaris, organisasi profesi Notaris maupun terhadap masyarakat. 


\section{DAFTAR KEPUSTAKAAN}

G.H.S. Lumban Tobing,1983. Peraturan Jabatan Notaris, Erlangga, Jakarta.

Roesnatiti, Kode Etik. Notaris, Makalah disampaikan pada kuliah Kode Etik Notaris semester dua Program Studi Magister Kenotariatan Universitas Indonesia, Depok, Maret 2009.

Peter Mahmud Marzuki, 2010, Penelitian Hukum, cetakan ke enam, Kencana, Jakarta.

F. Sugeng Istanto, 2007, Penelitian Hukum, CV. Ganda, Yogyakarta,. dipetik dari Saldi Isra, 2009. Pergeseran Fungsi Legislasi dalam Sistem Pemerintahan Indonesia Setelah Perubahan Undang-Undang Dasar 1945, Disertasi Program Pascasarjana Fakultas Hukum Universitas Gadjah Mada, Yogyakarta.

Saldi Isra, 2014. Sistem Rekruitmen dan Pengangkatan Hakim Agung dan Hakim Konstitusi dalam Konsepsi Negara Hukum, Penelitian Badan Pembinaan Hukum Nasional (BPHN) Tahun 2014, Jakarta Sugiyono, 2009, Metode Penelitian Bisnis, CV. Alfabeta, Bandung.

Bambang Sunggono,2003, Metodologi Penelitian Hukum Edisi II Cet.5, JPT. Raja Grafindo Persada, Jakarta.

Wawancara Arif Endra Susilo, SH, Sekretaris MPD Notaris Kota Padang, Pada tanggal 14 September 2019, Pukul 10.00 WIB.

Azmi Fendri, Strategi Notaris Dalam Menghadapi Perkara Pidana/Perdata Dalam Kaitannya Dengan Kewenangan MPD dan MKN, Makalah disampaikan pada Acara Up Grading Ikatan Notaris Indonesia Wilayah Sumatera Barat Pengurus Daerah Pariaman tanggal 27 Maret 2017 , di Pariaman. http://mkn.usu.ac.id/images/9.pdf, di akses tanggal 2 Desember 2019, pukul $10.00 \mathrm{WIB}$

Christin Sasauw, 2015, Tinjauan Yuridis Tentang Kekuatan Mengikat Suatu Akta Notaris, Jurnal Lex Privatum, Vol.III/No.1. 